\title{
PENGARUH KESADARAN LINGKUNGAN TERHADAP PERSEPSI KONSUMEN DAN NIATBELI PRODUK LAMPU LED PHILIPS DIKOTA DENPASAR
}

\author{
A.A. Ngurah Bagus Jaya Krisnanda ${ }^{1}$ \\ I Nyoman Nurcaya ${ }^{2}$ \\ ${ }^{1.2}$ Fakultas Ekonomi dan Bisnis Universitas Udayana (Unud), Bali, Indonesia \\ e-mail:gungkrisna182@gmail.com
}

\begin{abstract}
ABSTRAK
Tujuan penelitian ini adalah untuk menjelaskan pengaruh kesadaran lingkungan terhadap persepsi konsumen pada produk lampu LED Philips, untuk mengetahui pengaruh kesadaran lingkungan dan persepsi konsumen terhadap niat beli produk Lampu LED Philips, serta untuk mengetahui peran persepsi konsumen dalam memediasi variabel kesadaran lingkungan terhadap niat beli produk Lampu LED Philips. Populasi dalam penelitian ini adalah konsumen yang memiliki keinginan membeli lampu LED Philips di Kota Denpasar. Teknik pengambilan sampel yang digunakan adalah metode purposive sampling. Jumlah sampel yang digunakan dalam penelitian ini sebanyak 110 sampel. Teknik analisis dalam penelitian ini menggunakan teknik analisis jalur (Path Analysis). Hasil penelitian menunjukkan bahwa kesadaran lingkungan berpengaruh positif dan signfikan terhadap persepsi konsumen pada produk Lampu LED Philips di Kota Denpasar. Kesadaran lingkungan berpengaruh positif dan signfikan terhadap niat beli produk Lampu LED Philips di Kota Denpasar. Persepsi konsumen berpengaruh positif dan signifikan terhadap niat beli produk Lampu LED Philips di Kota Denpasar. Persepsi konsumen secara positif dan signifikan memediasi pengaruh kesadaran lingkungan terhadap niat beli produk lampu LED di Kota Denpasar.
\end{abstract}

Kata kunci:kesadaran lingkungan, persepsi konsumen, niat beli

\begin{abstract}
The purpose of this research is to explain the influence of environmental awareness to consumer perception on Philips LED lighting product, to know the influence of environmental awareness and consumer perception on buying intention of Philips LED Lights product, and to know consumer perception role in mediating environmental awareness variable to purchase product intention Lamp Philips LED. The population in this study are consumers who have the desire to buy Philips LED lights in the city of Denpasar. The sampling technique used is purposive sampling method. The number of samples used in this study as many as 110 samples. Analysis technique in this research using path analysis technique (Path Analysis). The results showed that environmental awareness has positive and significant impact on consumer perception on Philips LED Lights product in Denpasar City. Environmental awareness has a positive and significant impact on purchase intention of Philips LED Lights in Denpasar City. Consumer perceptions have a positive and significant effect on purchase intention of Philips LED Lights in Denpasar City. Consumer perceptions positively and significantly mediate the influence of environmental awareness on purchasing intentions of LED lighting products in Denpasar City.
\end{abstract}

Keywords: environmental awareness, consumer perception, intention to buy 
A.A. Ngurah Bagus Jaya Krisnandadan I Nyoman Nurcaya, Pengaruh Kesadaran ...

\section{PENDAHULUAN}

Pemanasan global merupakan suatu masalah yang banyak dibicarakan oleh masyarakat luas. Dampak tersebut dapat mempengaruhi hampir dari seluruh aspek kehidupan masyarakat. Informasi mengenai pemanasan global dan perubahan iklim semakin marak terjadi, hal ini telah banyak diutarakan oleh pemerintah, LSM, media, maupun institusi pendidikan kepada masyarakat. Isu-isu mengenai lingkungan di Indonesia semakin meningkat dan membuat kesadaran konsumen di Indonesia turut memperhatikan isu tersebut, ini ditandai dengan banyaknya aksi kampanye pencegahan pemanasan global yang diprakarsai oleh pemerintah, LSM, media, maupun institusi pendidikan dan mendapat banyak sorotan dari masyarakat dan sorotan media (Naratama dan Nurcaya, 2016).

Salah satu aksi pemerintah dalam upaya mencegah pemanasan global adalah menggelar kampanye hemat energi bertajuk "Gerakan Potong 10 Persen". Direktorat Jenderal Energi Baru Terbarukan dan Konservasi Energi (EBTKE) menyampaikan bahwa Menteri Energi dan Sumber Daya Mineral (ESDM), Sudirman Said, mengajak masyarakat untuk melakukan hemat energi melalui "Gerakan Potong 10 persen" di acara Car Free Day secara serentak di tiga kota, yaitu Denpasar, Makassar, dan Balikpapan.

Bertambahnya perhatian mengenai keadaan lingkungan beserta dampaknya dalam kehidupan sosial oleh berbagai pihak ini, mampu mendorong kesadaran masyarakat pada lingkungan sekitarnya. Sejak beberapa dekade terakhir kesadaran lingkungan masyarakat dunia akan pentingnya pelestarian lingkungan semakin meningkat, peningkatan ini dicetuskan oleh adanya kekhawatiran terjadinya 
bencana yang mengancam lingkungan hidup, bukan hanya kesehatan, bahkan sampai pada kelangsungan hidup manusia dan keturunannya. Situasi seperti itu akhirnya munculah apa yang disebut green consumerism. Green consumerism adalah kelanjutan dari gerakan konsumerisme global yang dimulai dengan adanya kesadaran konsumen akan hak-haknya untuk mendapatkan produk yang layak, aman, dan produk yang ramah lingkungan (environment friendly) yang semakin kuat (Margiyanti, 2013).Hasil survei WWF-Indonesia dan Nielsen survey tahun 2017 menunjukkan sebanyak 63\% konsumen Indonesia bersedia mengonsumsi produk ramah lingkungan dengan harga yang lebih tinggi. Hal ini menunjukkan peningkatan kesadaran konsumen yang signifikan terhadap konsumsi produk ramah lingkungan dan mengindikasikan kesiapan pasar domestik menyerap produk-produk yang diproduksi secara berkelanjutan(Adhityahadi dan Handayani, 2017).

Salah satu produk ramah lingkungan terkait penghematan energi listrik yang saat ini tengah dikembangkan oleh para produsen elektronik terkenal adalah lampu LED (Light Emiting Dioda) hemat energi. Pemerintah dapat meringankan beban biaya listrik melalui pemanfaatan lampu LED secara nasional. Pemanfaatan Lampu LED Nasional akan memberikan benefit yang besar bagi masyarakat kalangan bersubsidi listrik. Sehingga masyarakat pada umumnya akan lebih diuntungkan dengan terjadinya penghematan biaya pembelian lampu (Rachmantoyo, 2017).Pelaku industri lampu memprediksi konsumsi lampu light emitting diode (LED) tahun ini tumbuh $233 \%$ dari 12 juta unit menjadi 40 juta unit, seiring permintaan masyarakat yang kian meningkat. Ketua Umum Asosiasi 
A.A. Ngurah Bagus Jaya Krisnandadan I Nyoman Nurcaya, Pengaruh Kesadaran ...

Industri Perlampuan Indonesia (Aperlindo) John Manoppo menyakini penggunaan lampu LED akan menggeser lampu hemat energi (LHE) yang selama ini menyasar pasar rumah tangga hingga 95\%. Menurutnya, kehadiran lampu LED yang menawarkan produk lebih hemat dari LHE serta harga lebih terjangkau oleh hampir lapisan masyarakat, maka permintaan LED akan terus tumbuh tiap tahun (Khamdi, 2014). Salah satu perusahaan yang menangkap peluang atas kondisi meningkatnya permintaan terhadap lampu LED tersebut adalah Philips Lighting Company.Survei yang dilakukan mulai bulan April hingga Mei 2017 dengan melibatkan 12.000 konsumen pria dan wanita berusia antara 15 sampai 65 tahun dengan berbagai latar belakang sosial ekonomi, di 15 kota besar di Indonesia memperoleh hasil bahwa Philips Lighting unggul meraih indeks tertinggi hingga 80 persen dibandingkan dengan perusahaan lainnya dalam tiga faktor pengukuran: top of mind (merek yang pertama kali disebut), last used (merek yang terakhir kali digunakan) dan future intention (merek yang ingin digunakan di masa mendatang) (Agustina, 2017).

Masyarakat di tuntut untuk terus berkembang meningkatkan kualitas kehidupannya seiring dengan perkembangan lingkungan pemasaran yang cukup pesat. Dalam perkembangan pada dunia industri, persaingan di antara perusahaanperusahaan pun semakin ketat. Sedangkan permasalahan sosial dan lingkungan saling bermunculan seiring dengan banyak perusahaan-perusahaan baru yang bergerak di bidang yang sejenis maupun berbeda jenis. Suatu perusahaan dituntut untuk harus dapat memenuhi semua keinginan dan kebutuhan yang di minta oleh para konsumen (Rizky Kharismawan, 2013). 
Penting bagi para pemasar untuk mengetahui faktor apa saja yang dapat membentuk niat beli konsumen pada produk ramah lingkungan. Saputra (2016) dalam penelitiannya menyatakan bahwa variasi niat beli dapat dijelaskan oleh variasi dari variabel konsekuensi individual, konsekuensi lingkungan, harga premium, afek ekologikal, pengetahuan ekologikal dan kesadaran lingkungan. Variabel kesadaran lingkungan berpengaruh secara signifikan terhadap niat beli produk hijau (Margiyanti, 2013). Kesadaran lingkungan konsumen ini memberikan gambaran bahwa kesadaran konsumen terhadap lingkungan mempengaruhi keinginannya untuk membayar dengan harga premium untuk produk produk ramah lingkungan. Sikap kesadaran terhadap lingkungan ternyata juga mempunyai pengaruh yang signifikan pada tingkat keterlibatan konsumen dalam pemilihan produk yang dilakukan konsumen. Tingkat keterlibatan konsumen dalam proses pencarian informasi tentang produk-produk ramah lingkungan ini mendorong konsumen untuk berkeinginan untuk melakukan pembelian produk hijau pada masa mendatang (Junaedi, 2015). Penelitian oleh Setyadarma, dkk (2012) memperoleh hasil bahwa kesadaran lingkungan berpengaruh signifikan terhadap niat beli produk ramah lingkungan. Sedangkan, penelitian Saputra (2016) memperoleh hasil bahwa kesadaran lingkungan tidak berpengaruh terhadap niat beli produk hijau.

Selain faktor kesadaran konsumen, niat beli juga dipengaruhi oleh persepsi konsumen. Penelitian yang dilakukan oleh Lubis (2017) memperoleh hasil bahwa persepsi konsumen berpengaruh signifikan terhadap niat beli. Persepsi merupakan salah satu dari berbagai faktor yang mempengaruhi pilihan konsumen terhadap 
A.A. Ngurah Bagus Jaya Krisnandadan I Nyoman Nurcaya, Pengaruh Kesadaran ...

produk. Biasanya konsumen yang termotivasi tentang suatu produk telah siap untuk melakukan pembelian. Namun, bagaimana seseorang bertindak dipengaruhi oleh persepsinya mengenai situasi tertentu. Persepsi kinerja produk dan kemampuan konsumen untuk melakukan penilaian sangat tergantung pada atributatribut intrinsik yang menjadi perhatian konsumen (Yohanna, 2013). Menurut Saputra dan Samuel, (2013) persepsi mempunyai hubungan yang berpengaruh positif signifikan terhadap niat beli. Hal ini berarti konsumen yang menjadi responden penelitian menganggap persepsi sebagai faktor yang ikut menentukan keputusan pembelian konsumen. Namun, penelitian Sari dkk. (2015) serta Chen dan Chang (2012) memperoleh hasil bahwa persepsi berpengaruh negatif dan signifikan terhadap niat beli.

Pantouw et al.(2017) dalam penelitiannya menyebutkan bahwa persepsi konsumen berpengaruh signifikan terhadap niat beli produk ramah lingkungan. Hal ini menunjukkan bahwa semakin tinggi kesadaran seseorang terhadap lingkungannya maka semakin tinggi pula persepsi mereka terhadap produk ramah lingkungan. Persepsi terhadap produk ramah lingkungan dapat ditingkatkan dengan meningkatkan kesadaran seseorang terhadap lingkungannya sehingga semakin tinggi pula minatnya dalam membeli produk ramah lingkungan. Hasil ini sesuai juga dengan penelitian yang di dahului oleh Naratama (2014) terhadap niat beli dan produk hijau di Kota Denpasar. niat beli produk hijau adalah suatu kencenderungan seseorang untuk melakukan tindakan pembelian berkaitan dengan sikapnya terhadap suatu produk ramah lingkungan (Julianti dan Pramudana, 2017). 
Terdapat dua faktor yang mempengaruhi niat beli seorang konsumen (Kotler dan Keller, 2012). Kedua faktor tersebut adalah sikap dari orang lain (attitude of others) dan situasi yang tidak terduga (unanticipated situasional). Faktor pertama adalah sikap dari orang lain. Hal ini bergantung pada seberapa besar sikap negatif atau positif orang lain terhadap pilihan seorang konsumen. Kemudian motivasi konsumen tersebut untuk memenuhi keinginan orang lain. Faktor kedua adalah situasi yang tidak terduga. Faktor ini dapat menyebabkan perubahan terhadap keputusan pembelian seorang konsumen. Sebagai contoh, seseorang konsumen berniat untuk membeli suatu produk, namun karena terjadi sesuatu hal yang tidak terduga pada dirinya maka konsumen tersebut mengubah niat belinya.

Kondisi lingkungan saat ini yang tidak stabil membuat konsumen dihadapkan oleh pilihan untuk melakukan pembelian yang lebih bijak. Kesadaran lingkungan konsumen menjadi salah satu acuan yang dapat digunakan saat menyusun niat dalam mengkonsumsi suatu produk. Sehingga diharapkan apa yang dikonsumsinya dapat berdampak baik terhadap lingkungannya (Rohdiyah, 2012). Berdasarkan latar belakang yang telah dipaparkan dan masih adanya kontradiktif hasil penelitian sebelumnya tentang pengaruh kesadaran lingkungan dan persepsi konsumen terhadap niat pembelian, maka tujuan dari penelitian ini untuk menjelaskan pengaruh kesadaran lingkungan terhadap persepsi konsumen dan niat beli produk Lampu LED Philips, untuk menjelaskan pengaruh persepsi konsumen terhadap niat beli produk Lampu LED Philips, dan untuk menjelaskan peran variabel persepsi konsumen dalam memediasi variabel kesadaran lingkungan terhadap niat beli produk Lampu LED Philips. 
A.A. Ngurah Bagus Jaya Krisnandadan I Nyoman Nurcaya, Pengaruh Kesadaran ...

Berdasarkan telaah dan kajian penelitian terdahulu, maka dapat disusun hipotesis sebagai berikut:

$\mathrm{H}_{1}$ : kesadaran lingkungan terhadap produk hijau memiliki pengaruh positif terhadap persepsi konsumen

$\mathrm{H}_{2}$ : kesadaran lingkungan hijau memiliki pengaruh positif terhadap niat beli.

$\mathrm{H}_{3}$ : persepsi konsumen memiliki pengaruh positif terhadap niat beli.

$\mathrm{H}_{4}$ : kesadaran lingkungan berpengauh langsung dan tidak langsung terhadap niat beli melalui persepsi konsumen

Berdasarkan kajian penelitian terdahulu dan hipotesis yang sudah dirumuskan, maka model konseptual dalam penelitian ini adalah sebagai berikut:

\section{Gambar 1. Model Penelitian}

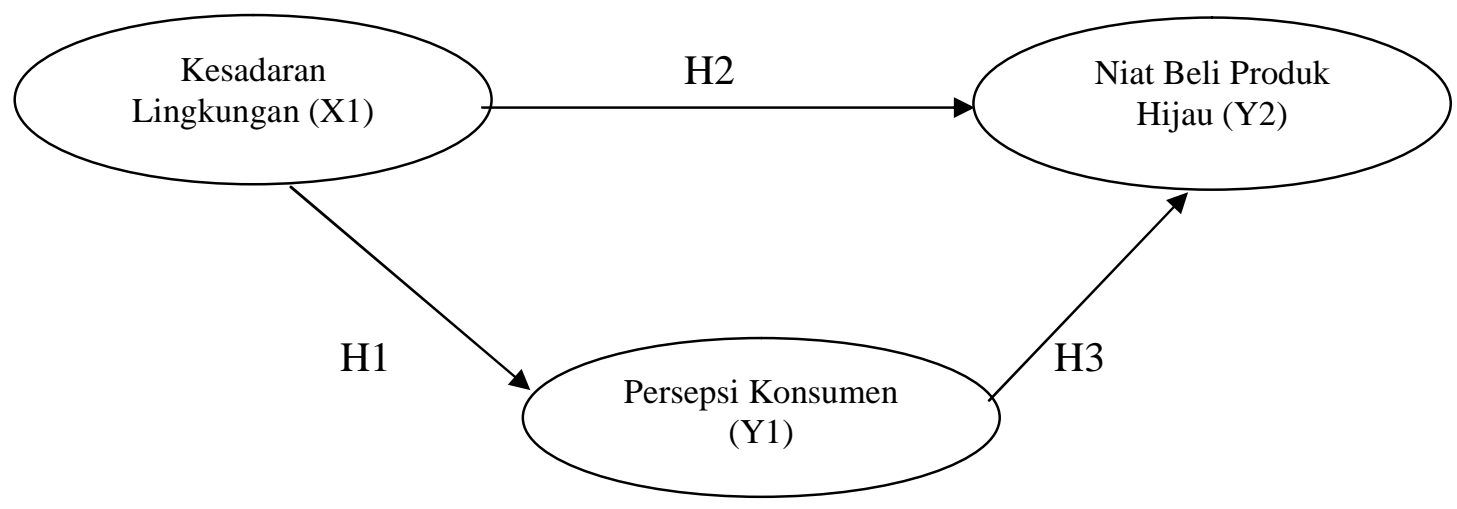

Sumber : Margiyanti (2013) dan Sari dkk. (2015)

\section{METODE PENELITIAN}

Pendekatan yang digunakan dalam penelitian ini adalah pendekatan kuantitatif berbentuk asosiatif yaitu suatu pendekatan yang mampu menunjukan hubungan variabel kesadaran lingkungan, persepsi konsumen dengan niat beli. Penelitian ini di lakukan di Kota Denpasar. Lokasi ini di pilih karena Kota Denpasar adalah daerah urban dengan pertumbuhan sektor ekonomi 
masyarakatnya sangat cepat, dalam hal ini selera masyarakat yang sudah berubah dapat ditangkap dengan jelas.

Penelitian ini menggunakan tiga variabel yaitu variabel bebas, variabel intervening dan variabel terikat, yang secara rinci dirangkum dalam Tabel 1.

\section{Tabel 1.}

\section{Rangkuman Variabel dan Idikator Penelitian}

\begin{tabular}{|c|c|c|c|}
\hline No. & Variabel & Indikator & Referensi \\
\hline 1. & $\begin{array}{l}\text { Kesadaran } \\
\text { Lingkungan }\end{array}$ & $\begin{array}{l}\text { 1. Pengetahuan responden akan lingkungan. } \\
\text { 2. Sikap positif responden akan lingkungan } \\
\text { 3. Tindakan responden terhadap lingkungan } \\
\text { 4. Tindakan responden dalam membeli produk yang } \\
\text { didaur ulang }\end{array}$ & $\begin{array}{l}\text { Setyadarma, } \\
\text { dkk (2012) }\end{array}$ \\
\hline 2. & $\begin{array}{l}\text { Persepsi } \\
\text { Konsumen }\end{array}$ & $\begin{array}{l}\text { 1. Lampu LED Philips lebih hemat energi } \\
\text { dibandingkan lampu pijar } \\
\text { 2. Lampu LED Philips memiliki iklan yang sangat } \\
\text { menarik terkait produk ramah lingkungan } \\
\text { 3. Harga Lampu LED Philip sesuai dengan manfaat } \\
\text { yang diperoleh } \\
\text { 4. Lampu LED merk philips lebih dapat dipercaya } \\
\text { karena Philips Lighting Company memiliki citra } \\
\text { yang baik }\end{array}$ & $\begin{array}{l}\text { Pantouw, et } \\
\text { al (2017) }\end{array}$ \\
\hline 3. & $\begin{array}{l}\text { Niat } \\
\text { pembelian } \\
\text { produk hijau }\end{array}$ & $\begin{array}{l}\text { 1. Tertarik untuk mencoba produk lampu LED Philips } \\
\text { 2. Mempertimbangkan untuk membeli produk lampu } \\
\text { LED Philip } \\
\text { 3. Akan beralih ke produk lampu LED Philipapabila } \\
\text { ingin berganti lampu }\end{array}$ & $\begin{array}{l}\text { Aman et al. } \\
(2012) \text { dan } \\
\text { Usadi } \\
(2015)\end{array}$ \\
\hline
\end{tabular}

Sumber: Kajian penelitian sebelumnya, 2018

Populasi dalam penelitian ini adalah masyarakat Kota Denpasar, sedangkan responden dalam penelitian ini adalah konsumen di Kota Denpasar yang mempunyai keinginan menggunakan lampu LED Philips. Teknik pengambilan sampel yang digunakan adalah metode purposive sampling yaitu penentuan sampel dengan menggunakan kriteria yang terdiri responden berdomisili di Kota Denpasar yang menempuh jenjang pendidikan minimal SMA dan sudah memiliki pekerjaan serta belum pernah membeli produk lampu LES Philips dan memiliki niat untuk membeli lampu LED Philips. Jadi jumlah sampel yang digunakan 
A.A. Ngurah Bagus Jaya Krisnandadan I Nyoman Nurcaya, Pengaruh Kesadaran ...

dalam penelitian ini sebanyak 110 orang konsumen yang memiliki niat untuk membeli produk lampu LED Philips.

Metode pengumpulan data yang digunakan dalam penelitian ini adalah data dikumpulkan dengan menggunakan kuesioner. Data yang sudah terkumpul, kemudian diuji kelayakannya dengan menggunakan uji validitas, reliabilitas dan analisis faktor konfirmatori. Data yang sudah dinyatakan layak selanjutnya dianalisis menggunakan analisis statistik deskriptif, dan analisis jalur atau biasa disebut path analysis. Model path analysis dipakai untuk menganalisis pola hubungan antar variabel dengan tujuan untuk mengetahui pengaruh langsung ataupun tidak langsung suatu variabel bebas (kesadaran ligkungan) terhadap variabel terikat (Niat Beli) dengan persamaan berikut:

Substruktur 1

$\mathrm{Y} 1=\beta 1 \mathrm{X}+\varepsilon 1$

Substruktur 2

$\mathrm{Y} 2=\beta 2 \mathrm{X}+\beta 3 \mathrm{Y} 1+\varepsilon 2$

\section{Keterangan :}

Y2 = Niat Beli

Y1 = Persepsi Konsumen

$\mathrm{X}=$ Kesadaran Lingkungan

$\beta 1, \beta 2, \beta 3=$ koefisien regresi variabel

$\mathrm{e} \quad=$ error

Untuk menguji kekuatan pengaruh tidak langsung variabel kesadaran lingkungan $(\mathrm{X})$ terhadap variabel niat beli $\left(\mathrm{Y}_{2}\right)$ melalui variabel persepsi konsumen $\left(\mathrm{Y}_{1}\right)$ dihitung menggunakan uji sobel dengan rumus berikut ini:

$\mathrm{Sab}=\sqrt{\mathrm{b}^{2} \mathrm{Sa}^{2}+\mathrm{a}^{2} \mathrm{Sb}^{2}+\mathrm{Sa}^{2} \mathrm{Sb}^{2}}$ 
Untuk menguji signifikansi pengaruh tidak langsung maka nilai $\mathrm{z}$ dari koefisien ab dihitung dengan rumus sebagai berikut :

$Z=\frac{a}{S}$

Keterangan:

$\mathrm{Sab}=$ besarnya standard error tidak langsung

$\mathrm{Sa} \quad=$ standard error koefisien a

$\mathrm{Sb}=$ standard error koefisien $\mathrm{b}$

a $\quad=$ koefisien jalur $\mathrm{X}_{1}$ terhadap $\mathrm{Y}_{1}$

$\mathrm{b} \quad=$ koefisien jalur $\mathrm{Y}_{1}$ terhadap $\mathrm{Y}_{2}$

\section{HASIL DAN PEMBAHASAN}

Sebelum melakukan analisis regresi linier berganda, instrumen penelitian diuji kelayakannya menggunakan uji validitas, reliabilitas dan analisis faktor konfirmatori. Hasil pengujian instrumen dalam penelitian ini terangkum dalam Tabel 2. Hasil uji pada tabel 2 menunjukkan bahwa seluruh instrumen penelitian yang digunakan untuk mengukur variabel kesadaran lingkungan, persepsi konsumen, dan niat beli memiliki nilai koefisien korelasi dengan skor total seluruh item pernyataan lebih besar dari 0,30 dengan signifikansi kurang dari 0,05 dan memiliki nilai koefisien Cronbach's Alpha lebih dari 0,60, serta memiliki nilai $\mathrm{KMO}>0,5$. Hal ini menunjukkan bahwa butir-butir pernyataan dalam instrument penelitian tersebut valid, reliabel, dan memiliki kecukupan sampel untuk analisis faktor, sehingga layak digunakan sebagai instrumen penelitian.

Tabel 3 menunjukkan kesadaran lingkungan pada responden yang diteliti termasuk dalam kriteria yang tinggi. Hasil penyebaran kuisioner menunjukan secara keseluruhan rata-rata jawaban responden memiliki nilai sebesar 4,05. Nilai 
A.A. Ngurah Bagus Jaya Krisnandadan I Nyoman Nurcaya, Pengaruh Kesadaran ...

rata-rata tertinggi terdapat pada pernyataan "Saya akan membeli produk ramah lingkungan dalam waktu dekat" dengan nilai rata-rata 4,14. Hal ini menunjukan bahwa secara keseluruhan responden akan membeli produk ramah lingkungan dalam waktu dekat. Nilai rata-rata terendah terdapat pada pernyataan "Saya mengikuti aksi hemat energi dengan cara mengurangi penggunaan jumlah listrik ", dengan nilai rata-rata sebesar 3,95. Hal ini menunjukkan bahwa masih ada responden yang tidak mengetahui aksi hemat energi demi membantu pemerintah mengatasi masalah krisis energi.

Tabel 2.

Rekapitulasi Hasil Uji Instrumen Penelitian

\begin{tabular}{|c|c|c|c|c|c|c|c|}
\hline $\begin{array}{l}\mathbf{N} \\
\mathbf{o}\end{array}$ & Variabel & $\begin{array}{c}\text { Indikato } \\
\mathbf{r}\end{array}$ & $\begin{array}{c}\text { Korelas } \\
\text { i Item }\end{array}$ & $\begin{array}{c}\text { Sig. } \\
(2- \\
\text { tailed } \\
)\end{array}$ & $\begin{array}{c}\text { Cronbadh' } \\
\text { s Alpha }\end{array}$ & $\begin{array}{c}\text { Kaise } \\
r \\
\text { Meyer } \\
\text { Olkin }\end{array}$ & $\begin{array}{c}\text { Keteranga } \\
\mathbf{n}\end{array}$ \\
\hline \multirow{4}{*}{1} & \multirow{4}{*}{$\begin{array}{c}\text { Kesadaran } \\
\text { Lingkunga } \\
\mathrm{n} \\
\text { (X) }\end{array}$} & $\mathrm{X}_{1}$ & 0,849 & 0,000 & \multirow{4}{*}{0,833} & \multirow{4}{*}{0,778} & \multirow{4}{*}{$\begin{array}{l}\text { Valid dan } \\
\text { Reliabel }\end{array}$} \\
\hline & & $\mathrm{X}_{2}$ & 0,802 & 0,000 & & & \\
\hline & & $\mathrm{X}_{3}$ & 0,872 & 0,000 & & & \\
\hline & & $\mathrm{X}_{4}$ & 0,741 & 0,000 & & & \\
\hline \multirow{5}{*}{2} & \multirow{4}{*}{$\begin{array}{l}\text { Persepsi } \\
\text { Konsumen } \\
\text { (Y1) }\end{array}$} & $\mathrm{Y}_{1.1}$ & 0,669 & 0,000 & \multirow{5}{*}{0,698} & \multirow{5}{*}{0,652} & \multirow{4}{*}{$\begin{array}{c}\text { Valid dan } \\
\text { Reliabel }\end{array}$} \\
\hline & & $\mathrm{Y}_{1.2}$ & 0,578 & 0,000 & & & \\
\hline & & $\mathrm{Y}_{1.3}$ & 0,801 & 0,000 & & & \\
\hline & & $\mathrm{Y}_{1.4}$ & 0,836 & 0,000 & & & \\
\hline & \multirow{3}{*}{$\begin{array}{l}\text { Niat Beli } \\
\text { (Y2) }\end{array}$} & $\mathrm{Y}_{2.1}$ & 0,700 & 0,000 & & & \multirow{3}{*}{$\begin{array}{l}\text { Valid dan } \\
\text { Reliabel }\end{array}$} \\
\hline \multirow[t]{2}{*}{3} & & $\mathrm{Y}_{2.2}$ & 0,813 & 0,004 & \multirow[t]{2}{*}{0,649} & \multirow[t]{2}{*}{0,624} & \\
\hline & & $\mathrm{Y}_{2.3}$ & 0,786 & 0,000 & & & \\
\hline
\end{tabular}

Sumber :Data primer diolah, 2018

Tabel 3.

Deskripsi Jawaban Responden Terhadap Kesadaran lingkungan

\begin{tabular}{|c|c|c|c|c|c|c|c|c|}
\hline \multirow{2}{*}{ No } & \multirow{2}{*}{ Pernyataan } & \multicolumn{5}{|c|}{ Frekuensi Jawaban Responden } & \multirow{2}{*}{$\begin{array}{l}\text { Rata- } \\
\text { Rata }\end{array}$} & \multirow{2}{*}{ Kriteria } \\
\hline & & STS & TS & $\mathbf{N}$ & $\mathbf{S}$ & SS & & \\
\hline 1 & $\begin{array}{l}\text { Saya mengetahui dengan baik } \\
\text { kondisi linkungan saat ini }\end{array}$ & - & 6 & 20 & 50 & 34 & 4,02 & Tinggi \\
\hline
\end{tabular}




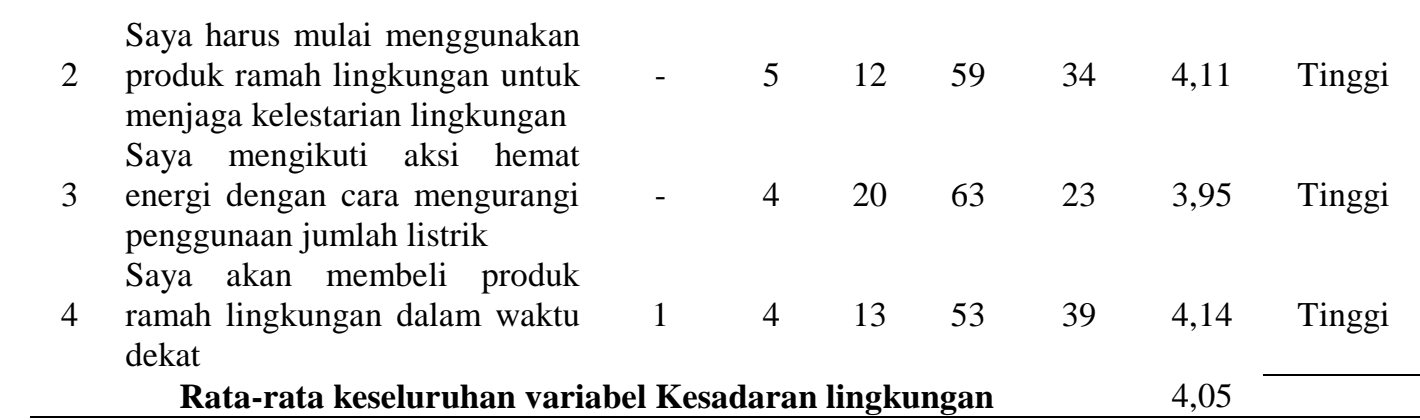
Sumber : Hasil Olahan Data, 2018

Tabel 4 menunjukkan secara keseluruhan rata-rata jawaban responden terhadap variabel persepsi konsumen memiliki nilai sebesar 3,98. Hasil penyebaran kuisioner menunjukkan bahwa responden penelitian memiliki persepsi yang baik pada produk lampu LED Philips. Nilai rata-rata tertinggi terdapat pada pernyataan "Lampu LED merk philips lebih dapat dipercaya karena Philips Lighting Company memiliki citra yang baik" dengan nilai rata-rata 4,15. Hal ini menunjukan bahwa secara keseluruhan responden memiliki persepsi yang baik pada perusahaan Philips, karena Philips Lighting Company memiliki citra yang baik, sehingga responden lebih percaya terhadap produk lampu LED Philips. Nilai rata-rata terendah terdapat pada pernyataan "Lampu LED Philips memiliki promosi yang sangat menarik terkait produk ramah lingkungan ", dengan nilai rata-rata sebesar 3,89. Hal ini menunjukan bahwa masih ada responden yang merasa promosi Lampu LED Philips kurang menarik. Hal ini disebabkan karena responden tidak pernah melihat perusahaan Philip menampilkan promosi yang menarik. Oleh karena itu, pihak manajemen dan marketing Philips sebaiknya membuat promosi lampu LED Philips yang lebih menarik yang menyatakan bahwa banyak kegunaan yang diperoleh bila menggunakan lampu LED Philips 
A.A. Ngurah Bagus Jaya Krisnandadan I Nyoman Nurcaya, Pengaruh Kesadaran ...

terutama terkait menghemat energi dan ketahanan produk, agar niat beli konsumen pada lampu LED Philip semakin meningkat.

Tabel 4.

Deskripsi Jawaban Responden Terhadap Variabel Persepsi konsumen

\begin{tabular}{|c|c|c|c|c|c|c|c|c|}
\hline \multirow{2}{*}{ No } & \multirow{2}{*}{ Pernyataan } & \multicolumn{5}{|c|}{ Frekuensi Jawaban Responden } & \multirow{2}{*}{$\begin{array}{l}\text { Rata- } \\
\text { Rata }\end{array}$} & \multirow{2}{*}{ Kriteria } \\
\hline & & STS & TS & $\mathbf{N}$ & $\mathbf{S}$ & SS & & \\
\hline 1 & $\begin{array}{l}\text { Lampu LED } \\
\text { hemat energi } \\
\text { dibanding lebih } \\
\text { lampu pijar }\end{array}$ & - & 3 & 24 & 55 & 28 & 3,98 & Baik \\
\hline 2 & $\begin{array}{l}\text { Lampu LED Philips memiliki } \\
\text { promosi yang sangat menarik } \\
\text { terkait produk ramah } \\
\text { lingkungan }\end{array}$ & - & 6 & 20 & 64 & 20 & 3,89 & Baik \\
\hline 3 & $\begin{array}{l}\text { Harga Lampu LED Philip } \\
\text { sesuai dengan manfaat yang } \\
\text { diperoleh }\end{array}$ & - & 4 & 24 & 58 & 24 & 3,93 & Baik \\
\hline 4 & $\begin{array}{l}\text { Lampu LED merk philips } \\
\text { lebih dapat dipercaya karena } \\
\text { Philips Lighting Company } \\
\text { memiliki citra yang baik }\end{array}$ & - & 5 & 9 & 60 & 36 & 4,15 & Baik \\
\hline & Rata-rata keseluruhan va & abel $P$ & sepsi & int & & & 3,98 & \\
\hline
\end{tabular}

Sumber : Hasil Olahan Data, 2018

Tabel 5 menunjukkan secara keseluruhan rata-rata jawaban responden terhadap variabel niat beli memiliki nilai sebesar 3,98. Hasil penyebaran kuisioner menunjukkan bahwa secara keseluruhan konsumen memiliki niat yang tinggi unutk membeli lampu LED Philips. Nilai rata-rata tertinggi terdapat pada pernyataan "Akan beralih ke produk lampu LED Philipapabila ingin berganti lampu" dengan nilai rata-rata 4,10. Hal ini menunjukan bahwa secara keseluruhan konsumen dalam penelitian ini akan beralih ke produk lampu LED Philipapabila 
ingin berganti lampu pijar di rumahnya. Nilai rata-rata terendah terdapat pada pernyataan “ Mempertimbangkan untuk membeli produk lampu LED Philip", dengan nilai rata-rata sebesar 3,84. Hal ini menunjukkan bahwa masih ada konsumen yang tidak memiliki niat untuk membeli produk lampu LED Philips. Hal ini bisa saja disebabkan karena konsumen merasa harga lampu LED Philips lebih mahal dibandingkan lampu biasa, dan konsumen tidak mengetahui apa saja keuntungan yang diperoleh bila menggunakan lampu LED Philips.

Tabel 5.

Deskripsi Jawaban Responden Terhadap Variabel Niat beli

\begin{tabular}{|c|c|c|c|c|c|c|c|c|}
\hline \multirow{2}{*}{ No } & \multirow{2}{*}{ Pernyataan } & \multicolumn{5}{|c|}{ Frekuensi Jawaban Responden } & \multirow{2}{*}{$\begin{array}{l}\text { Rata- } \\
\text { Rata }\end{array}$} & \multirow{2}{*}{ Kriteria } \\
\hline & & STS & TS & $\mathbf{N}$ & $\mathbf{S}$ & SS & & \\
\hline 1 & $\begin{array}{l}\text { Tertarik untuk mencoba } \\
\text { produk lampu LED Philips }\end{array}$ & - & 4 & 17 & 62 & 27 & 4,02 & Tinggi \\
\hline 2 & $\begin{array}{l}\text { Mempertimbangkan untuk } \\
\text { membeli produk lampu LED } \\
\text { Philip }\end{array}$ & - & 8 & 22 & 60 & 20 & 3,84 & Tinggi \\
\hline 3 & $\begin{array}{l}\text { Akan beralih ke produk lampu } \\
\text { LED Philipapabila ingin } \\
\text { berganti lampu }\end{array}$ & - & 7 & 13 & 52 & 38 & 4,10 & Tinggi \\
\hline \multicolumn{7}{|c|}{ Rata-rata keseluruhan variabel niat beli } & 3,98 & \\
\hline
\end{tabular}

Pengujian data dalam penelitian ini menggunakan teknik analisis jalur (Path Analysis). Perhitungan koefisien path jalur 1 yaitu pengaruh kesadaran lingkungan (X) terhadap persepsi konsumen (Y1), maka dapat dibuat persamaan struktural sebagai berikut :

$$
\begin{array}{ll}
\mathrm{Y} 1 & =\beta_{1} \mathrm{X}+\mathrm{e}_{1} \\
\mathrm{Y} 1 & =0,505 \mathrm{X}+\mathrm{e}_{1} \\
\mathrm{~S}_{\mathrm{e}} & =0,080 \\
\mathrm{t} & =6,084 \\
\text { Sig. } \mathrm{t} & =0,000 \\
\mathrm{R}^{2} & =0,255 \\
\mathrm{~F} & =37,012 \\
\text { Sig F } & =0,000
\end{array}
$$


A.A. Ngurah Bagus Jaya Krisnandadan I Nyoman Nurcaya, Pengaruh Kesadaran ...

Nilai koefisien regresi variabel kesadaran lingkungan bernilai positif dengan nilai signifikansi uji t kurang dari 0,05. Hal ini menunjukkan bahwa variabel kesadaran lingkungan memiliki pengaruh positif yang signifikan terhadap variabel persepsi konsumen. Besarnya pengaruh variabel bebas terhadap variabel terikat yang ditunjukkan oleh nilai determinasi total ( $\mathrm{R}$ Square) sebesar 0,255 mempunyai arti bahwa sebesar 25,5\% variasi persepsi konsumendipengaruhi oleh variasi kesadaran lingkungan, sedangkan sisanya sebesar 74,5\% dijelaskan oleh faktor lain yang tidak dimasukkan ke dalam model.

Perhitungan koefisien path jalur 2 yaitu pengaruh kesadaran lingkungan (X) terhadap persepsi konsumen (Y1), maka dapat dibuat persamaan struktural sebagai berikut :

$$
\begin{array}{lll}
\mathrm{Y}_{2} & =\beta_{2} \mathrm{X}+\beta_{3} \mathrm{Y}_{1}+\mathrm{e}_{2} \\
\mathrm{Y}_{2} & =0,223 \mathrm{X}+0,632 \mathrm{Y}_{1}+\mathrm{e}_{2} \\
\mathrm{~S}_{\mathrm{e}} & =0,070 & 0,072 \\
\mathrm{t} & =3,117 & 8,835 \\
\text { Sig. } & =0,002 & 0,000 \\
\mathrm{R}^{2} & =0,592 \\
\mathrm{~F} & =77,606 \\
\text { Sig F } & =0,000
\end{array}
$$

Nilai koefisien regresi masing-masing variabel bebas bernilai positif dengan nilai signifikansi uji t kurang dari 0,050. Hal ini menunjukkan bahwa semua variabel bebas memiliki pengaruh positif yang signifikan terhadap variabel terikat. Besarnya pengaruh variabel bebas terhadap variabel terikat yang ditunjukkan oleh nilai determinasi total (R Square) sebesar 0,592 mempunyai arti bahwa sebesar $59,2 \%$ variasi niat beli dipengaruhi oleh variasi kesadaran lingkungan dan persepsi konsumen, sedangkan sisanya sebesar $40,8 \%$ dijelaskan oleh faktor lain yang tidak dimasukkan ke dalam model. 
Berdasarkan model substruktur 1 dan substruktur 2, maka dapat disusun model diagram jalur akhir. Sebelum menyusun model diagram jalur akhir, terlebih dahulu dihitung nilai standar eror sebagai berikut :

$$
\begin{aligned}
& \mathrm{Pe}_{\mathrm{i}}=\sqrt{1-\mathrm{R}_{\mathrm{i}}{ }^{2}} \\
& \mathrm{Pe}_{1}=\sqrt{1-{R_{1}}^{2}}=\sqrt{1-0,255}=0,863 \\
& \mathrm{Pe}_{2}=\sqrt{1-R_{2}{ }^{2}}=\sqrt{1-0,592}=0,638
\end{aligned}
$$

Berdasarkan perhitungan pengaruh error (Pei), didapatkan hasil pengaruh error $\left(\mathrm{Pe}_{1}\right)$ sebesar 0,863 dan pengaruh error $\left(\mathrm{Pe}_{2}\right)$ sebesar 0,638. Hasil koefisien determinasi total adalah sebagai berikut :

$$
\begin{aligned}
\mathrm{R}^{2}{ }_{\mathrm{m}} & =1-\left(\mathrm{Pe}_{1}\right)^{2}\left(\mathrm{Pe}_{2}\right)^{2} \\
& =1-(0,863)^{2}(0,638)^{2} \\
& =1-(0,745)(0,407) \\
& =1-0,303=0,697
\end{aligned}
$$

Nilai determinasi total sebesar 0,697 mempunyai arti bahwa sebesar 69,7\% variasi niat beli dipengaruhi oleh variasi kesadaran lingkungandan persepsi konsumen, sedangkan sisanya sebesar 30,3\% djelaskan oleh faktor lain yang tidak dimasukkan ke dalam model.

Hasil koefisien jalur pada hipotesis penelitian dapat digambarkan pada Gambar 2 berikut :

Berdasarkan diagram jalur pada Gambar 2, maka dapat dihitung besarnya pengaruh langsung dan pengaruh tidak langsung serta pengaruh total antar variabel. Perhitungan pengaruh antar variabel dirangkum dalam Tabel 6 sebagai berikut.

Tabel 6 menunjukkan bahwa pengaruh langsung kesadaran lingkungan terhadap persepsi konsumenadalah sebesar 0,505. Pengaruh langsung variabel 
A.A. Ngurah Bagus Jaya Krisnandadan I Nyoman Nurcaya, Pengaruh Kesadaran ...

kesadaran lingkungan terhadap niat beli sebesar 0,223. Pengaruh langsung variabel persepsi konsumen terhadap niat beli sebesar 0,632. Hal ini berarti bahwa variabel niat beli lebih besar dipengaruhi oleh persepsi konsumen daripada kesadaran lingkungan. Sedangkan pengaruh tidak langsung variabel kesadaran lingkungan terhadap niat beli melalui persepsi konsumen sebesar 0,319.

\section{Gambar 2. Validasi Model Diagram Jalur Akhir}

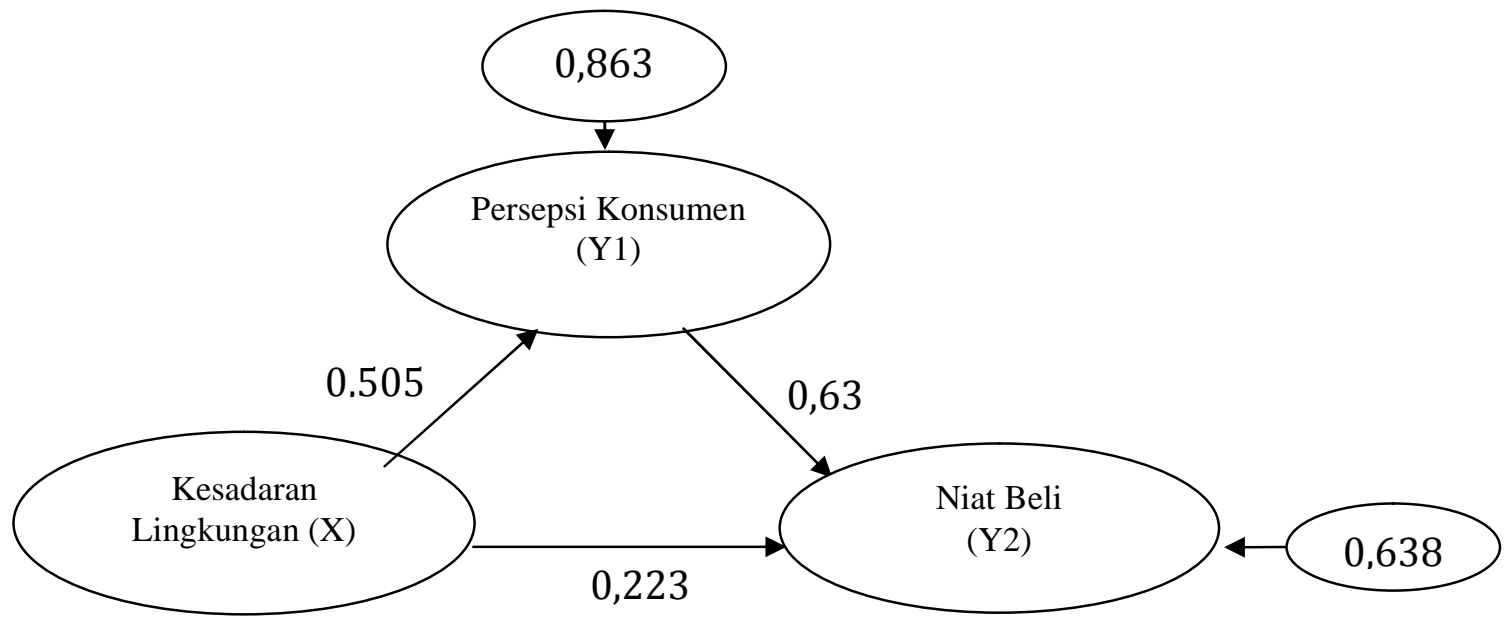

Sumber : Data primer diolah, 2018

Tabel 6.

Pengaruh Langsung dan Pengaruh Tidak Langsung serta Pengaruh Total Kesadaran lingkungan (X1), Persepsi konsumen (Y1), dan Niat beli (Y2)

\begin{tabular}{cccc}
\hline Pengaruh Variabel & $\begin{array}{c}\text { Pengaruh Tidak } \\
\text { Lengaruh } \\
\text { Langsung } \\
\text { Persepsi konsumen } \\
(\text { Y1 })(\boldsymbol{\beta 1} \mathbf{~ x 3})\end{array}$ & $\begin{array}{c}\text { Pengaruh } \\
\text { Total }\end{array}$ \\
\hline $\begin{array}{c}\text { Kesadaran Lingkungan } \rightarrow \text { Persepsi } \\
\text { Konsumen }\end{array}$ & 0,505 & - & 0,505 \\
$\begin{array}{c}\text { Kesadaran Lingkungan } \rightarrow \text { Niat Beli } \\
\text { Persepsi Konsumen } \rightarrow\end{array}$ & 0,223 & 0,319 & 0,542 \\
Niat Beli & 0,632 & - & 0,632 \\
\hline
\end{tabular}

Sumber :Data primer diolah, 2018

Jadi pengaruh total variabel kesadaran lingkungan terhadap niat beli melalui persepsi konsumen adalah sebesar 0,542, maka dapat disimpulkan bahwa niat beli konsumen pada produk Lampu LED Philips akan lebih besar bila 
konsumen memiliki kesadaran lingkungan dan persepsi yang baik terhadap produk lampu LED Philips.

Pengujian pengaruh tidak langsung variabel kesadaran lingkungan (X) terhadap variabel niat beli produk lampu LED Philips $\left(\mathrm{Y}_{2}\right)$ melalui variabel persepsi konsumen .

$\left(\mathrm{Y}_{1}\right)$, dilakukan menggunakan uji sobel dengan rumus sebagai berikut :

$$
\begin{aligned}
& S_{b 1 b 3}=\sqrt{(0,505)^{2}(0,072)^{2}+(0,632)^{2}(0,080)^{2}+(0,072)^{2}(0,080)^{2}} \\
& S_{b 1 b 3}=0,062542
\end{aligned}
$$

Untuk menguji signifikansi pengaruh tidak langsung maka menghitung nilai $\mathrm{z}$ dari koefisien ab dengan rumus sebagai berikut :

$$
\begin{aligned}
& Z=\frac{b 1 b 3}{S 1 b 3} \\
& Z=\underline{(0,505)(0,632)} \\
& 0,062542 \\
& Z=5,103 \text { dengan signifikansi } 0,000
\end{aligned}
$$

Oleh karena $\mathrm{Z}$ hitung sebesar 5,103 > 1,96. Artinya Persepsi konsumen $\left(\mathrm{Y}_{1}\right)$ merupakan variabel yang memediasi kesadaran lingkungan $(\mathrm{X})$ terhadap niat beli produk hijau $\left(\mathrm{Y}_{2}\right)$ atau dengan kata lain kesadaran lingkungan berpengaruh secara tidak langsung terhadap niat beli produk lampu LED Philips melalui persepsi konsumen.

\section{Pengaruh kesadaran lingkungan terhadap persepsi konsumen}

Berdasarkan hasil analisis pengaruh kesadaran lingkungan terhadap persepsi konsumen diperoleh nilai Signifikansi sebesar 0,000 dengan nilai koefisien beta 0,505. Nilai Signifikansi $0,000<0,05$ mengindikasikan bahwa $\mathrm{H}_{0}$ ditolak dan $\mathrm{H}_{1}$ diterima. Hasil ini mempunyai arti bahwa kesadaran lingkunganberpengaruh 
A.A. Ngurah Bagus Jaya Krisnandadan I Nyoman Nurcaya, Pengaruh Kesadaran ...

positif dan signifikan terhadap persepsi konsumen pada produk lampu LED Philips di Kota Denpasar. Hal ini memiliki makna bahwa semakin tinggi kesadaran konsumen pada lingkungan sekitar, maka semakin baik persepsi konsumen terhadap produk ramah lingkungan. Begitu pula sebaliknya, semakin rendah kesadaran lingkungan konsumen pada lingkungan sekitar, maka semakin burukpersepsi konsumen yang akan terbentuk pada produk ramah lingkungan.

Hasil tersebut mengindikasikan bahwa nilai - nilai yang terkandung dalam kesadaran lingkungan mampu dipersepsikan dengan baik dan berdampak nyata terhadap persepsi konsumen pada produk Lampu LED Philips. Kesadaran lingkungan yang diukur berdasarkan indikator: seberapa baik pengetahuan responden akan lingkungan, seberapa positif sikap responden akan lingkungan , seberapa besar kemungkinan tindakan responden akan lingkungan, dan seberapa besar kemungkinan tindakan responden dalam membeli produk ramah lingkungan terbukti mampu meningkatkan persepsi konsumen pada produk Lampu LED Philips di Kota Denpasar. Temuan ini dapat diartikan bahwa apabila intensitas penerapan kesadaran lingkungan oleh seluruh konsumen dapat ditingkatkan, maka akan mampu memberikan kontribusi yang signifikan untuk meningkatkan persepsi konsumen pada produk lampu LED Philips.

Penelitian ini mendukung beberapa hasil penelitian sebelumnya dan konsisten dengan hasil penelitian Paul dan Rana (2012) yang menemukan hasil bahwa kesadaran lingkungan berpengaruh positif dan signifikan terhadap persepsi konsumen. Penelitian tersebut menjelaskan bahwa kesadaran lingkungan yang dimiliki konsumen dapat berpengaruh secara langsung pada persepsi konsumen. 
Penelitian serupa yang dilakukan Follows dan Jobber (2000), Kim dan Chung (2011), Chen (2009) dan Gil (2001) juga memperoleh hasil bahwa kesadaran lingkungan mempunyai pengaruh yang positif terhadap persepsi konsumen.

\section{Pengaruh kesadaran lingkungan terhadap niat beli}

Berdasarkan hasil analisis pengaruh Kesadaran lingkungan terhadap Niat beli produk lampu LED Philips diperoleh nilai Signifikansi sebesar 0,002 dengan nilai koefisien beta 0,223. Nilai Signifikansi 0,002 <0,05 mengindikasikan bahwa $\mathrm{H}_{0}$ ditolak dan $\mathrm{H}_{2}$ diterima. Hasil ini mempunyai arti bahwa Kesadaran lingkunganberpengaruh positif dan signifikan terhadap Niat beli produk lampu LED Philips di Kota Denpasar. Hal ini memiliki makna bahwa semakin tinggi kesadaran konsumen pada lingkungannya, maka semakin tinggi niat beli konsumen pada produk ramah lingkungan. Begitu pula sebaliknya, semakin rendah kesadaran konsumen pada lingkungannya, maka semakin rendah niat beli konsumen pada produk ramah lingkungan.

Hasil tersebut mengindikasikan bahwa nilai - nilai yang terkandung dalam kesadaran lingkungan mampu dipersepsikan dengan baik dan berdampak nyata terhadap niat beli produk Lampu LED Philips di Kota Denpasat. Kesadaran lingkungan yang diukur berdasarkan indikator: seberapa baik pengetahuan responden akan lingkungan, seberapa positif sikap responden akan lingkungan, seberapa besar kemungkinan tindakan responden akan lingkungan, dan seberapa besar kemungkinan tindakan responden dalam membeli produk ramah lingkungan terbukti mampu meningkatkan niat beli konsumen pada produk Lampu LED 
A.A. Ngurah Bagus Jaya Krisnandadan I Nyoman Nurcaya, Pengaruh Kesadaran ...

Philips di Kota Denpasar. Temuan ini dapat diartikan bahwa apabila intensitas penerapan kesadaran lingkungan oleh seluruh konsumen dapat ditingkatkan, maka akan mampu memberikan kontribusi yang signifikan untuk meningkatkan niat beli konsumen pada produk lampu LED Philips di Kota Denpasar.

Penelitian ini mendukung beberapa hasil penelitian sebelumnya dan konsisten dengan hasil penelitian Saputra (2016) yang menunjukkan hasil bahwa kesadaran lingkungan berpengaruh positif dan signifikan terhadap niat beli produk ramah lingkungan. Hal tersebut berarti bahwa semakin tinggi kesadaran konsumen pada lingkungan, maka niat beli konsumen pada produk ramah lingkungan tersebut akan meningkat. Sebaliknya, semakin rendah pemahaman kesadaran lingkungan yang dimiliki konsumen, maka niat beli konsumen pada produk ramah lingkungan juga akan menurun. Penelitian serupa yang dilakukan Margiyanti (2013), Setyadarma dkk. (2012), Junaedi (2015), Paramita dan Yasa (2015), Yoo et al. (2013), dan Lee (2017) juga menemukan hasil bahwa variabel kesadaran lingkungan berpengaruh positif dan signifikan terhadap niat beli produk hijau.

\section{Pengaruh persepsi konsumen terhadap niat beli}

Berdasarkan hasil analisis pengaruh persepsi konsumen terhadap niat beli produk lampu LED Philips diperoleh nilai signifikansi sebesar 0,000 dengan nilai koefisien beta 0,632 . Nilai Signifikansi $0,000<0,05$ mengindikasikan bahwa $\mathrm{H}_{0}$ ditolak dan $\mathrm{H}_{3}$ diterima. Hasil ini mempunyai arti bahwa persepsi konsumen berpengaruh positif dan signifikan terhadap niat beli produk lampu LED Philips di Kota Denpasar. Hal ini memiliki makna bahwa semakin baik persepsi konsumen 
pada produk ramah lingkungan, maka semakin tinggi niat konsumen untuk membeli produk ramah lingkungan. Begitu pula sebaliknya, semakin buruk persepsi konsumen pada produk ramah lingkungan, maka semakin rendah niat konsumen untuk membeli produk ramah lingkungan.

Hasil tersebut mengindikasikan bahwa nilai - nilai yang terkandung dalam persepsi konsumen mampu dipersepsikan dengan baik dan berdampak nyata terhadap niat beli produk lampu LED Philips di Kota Denpasar. Persepsi konsumen yang diukur berdasarkan indikator: persepsi promosi, persepsi produk, persepsi harga, dan persepsi toko terbukti mampu meningkatkan niat beli produk lampu LED Philips di Kota Denpasar. Temuan ini dapat diartikan bahwa apabila konsumen memiliki persepsi yang baik pada produk ramah lingkungan, maka akan mampu memberikan kontribusi yang signifikan terhadap meningkatnya niat beli konsumen pada produk lampu LED Philips di Kota Denpasar.

Penelitian ini mendukung beberapa hasil penelitian sebelumnya dan konsisten dengan hasil penelitian Lubis (2017) memperoleh hasil bahwa persepsi konsumen berpengaruh signifikan terhadap niat beli. Persepsi merupakan salah satu dari berbagai faktor yang mempengaruhi pilihan konsumen terhadap produk. Biasanya konsumen yang termotivasi tentang suatu produk telah siap untuk melakukan pembelian. Namun, bagaimana seseorang bertindak dipengaruhi oleh persepsinya mengenai situasi tertentu. Penelitian serupa yang dilakukan Yohanna (2013), Saputra dan Samuel (2013), Pantouw et al. (2017), Julianti dan Pramudana (2017), Rizwan et al. (2013) dan Wardani dkk. (2015) juga memperoleh hasil bahwa persepsi konsumen berpengaruh positif dan signifikan 
A.A. Ngurah Bagus Jaya Krisnandadan I Nyoman Nurcaya, Pengaruh Kesadaran ...

terhadap niat beli produk hijau. Hal ini menunjukkan bahwa semakin tinggi kesadaran seseorang terhadap lingkungannya maka semakin tinggi pula persepsi mereka terhadap produk ramah lingkungan. Persepsi terhadap produk ramah lingkungan dapat ditingkatkan dengan meningkatkan kesadaran seseorang terhadap lingkungannya sehingga semakin tinggi pula minatnya dalam membeli produk.

\section{Peran persepsi konsumen memediasi pengaruh kesadaran lingkungan terhadap niat beli}

Apabila konsumen memiliki persepsi yang baik pada produk hijau dan konsumen juga memiliki kepedulian yang tinggi terhadap lingkungannya, maka sikap kesadaran lingkungan tersebut mampu meningkatkan persepsi konsumen dan pada akhirnya akan mampu meningkatkan niat beli konsumen pada produk ramah lingkungan. Berdasarkan hasil uji Sobel, ditemukan pengaruh yang positif antara variabel kesadaran lingkungan terhadap niat beli produk lampu LED Philips melalui variabel persepsi konsumen. Hasil penelitian ini didukung oleh penelitian yang dilakukanoleh Manget (2009) yang menemukan bahwa persepsi konsumen berpengaruh positif dan signifikan dalam memediasi kesadaran lingkungan terhadap niat beli konsumen pada produk hijau. Penelitian ini juga sejalan dengan penelitian yang dilakukan oleh Yan dan Chang (2006) yang menyatakan bahwa persepsi konsumen mampu memediasi pengaruh kesadaran lingkungan terhadap niat beli produk hijau. Dengan demikian, konsumen yang sudah memiliki kesadaran lingkungan akan memiliki persepsi yang baik pada produk ramah lingkungan, sehingga mampu meningkatkan niat beli produk hijau. Persepsi konsumen secara positif dan signifikan memediasi pengaruh kesadaran lingkungan 
terhadap niat beli produk lampu LED Philips di Kota Denpasar, memiliki makna bahwakesadaran lingkungan yang sudah tertanam dalam benak konsumen akan mampu meningkatkan niat beli produk hijau secara langsung dan tidak langsung melalui persepsi konsumen tersebut.

\section{SIMPULAN DAN SARAN}

Berdasarkan hasil analisis penelitian dan hasil pembahasan maka simpulan dari penelitian ini yaitu : 1) Kesadaran lingkungan berpengaruh positif dan signfikan terhadap persepsi konsumen pada produk Lampu LED Philips di Kota Denpasar. Hal ini menunjukan bahwa semakin tinggi kesadaran konsumen pada lingkungannya, maka semakin baik persepsi yang terbentuk dalam benak konsumen terhadap produk Lampu LED Philips. 2) Kesadaran lingkungan berpengaruh positif dan signifikan terhadap niat beli produk Lampu LED Philips di Kota Denpasar. Hal ini menunjukan bahwa semakin tinggi kesadaran konsumen pada lingkungan sekitarnya, maka dapat meningkatkan niat beli konsumen pada produk Lampu LED Philips. 3) Persepsi konsumen berpengaruh positif dan signifikan terhadap niat beli produk Lampu LED Philips di Kota Denpasar. Hal ini menunjukkan bahwa semakin baik persepsi konsumen pada produk yang ramah lingkungan, maka dapat meningkatkan niat konsumen untuk membeli produk Lampu LED di Kota Denpasar. 4) Persepsi konsumen secara positif dan signifikan memediasi pengaruh kesadaran lingkungan terhadap niat beli produk lampu LED di Kota Denpasar. Hal ini menunjukan bahwa kesadaran lingkungan yang dimiliki konsumen akan memberikan dampak yang signifikan terhadap niat beli produk hijau jika dimediasi oleh persepsi yang baik pada produk hijau, yang 
A.A. Ngurah Bagus Jaya Krisnandadan I Nyoman Nurcaya, Pengaruh Kesadaran ...

berarti bahwa niat beli konsumen pada produk lampu LED Philips di Kota Denpasar sangat tergantung pada tingkat persepsi konsumen yang dihasilkan dan juga tingkat kesadaran lingkungan.

Berdasarkan hasil analisis penelitian, pembahasan dan kesimpulan terdapat beberapa saran yang dapat dipergunakan sebagai bahan pertimbangan dalam menentukan kebijakan terkait niat beli produk lampu LED Philip di Kota Denpasar pada masa mendatang, yaitu dalam upaya meningkatkan kesadaran lingkungan konsumen menjadi lebih baik, maka pihak marketing lampu LED Philips sebaiknya mengajak masyarakat untuk melakukan aksi hemat energi dan memberitahukan masyarakat tentang pentingnya mengurangi penggunaan jumlah listrik dan menggunakan lampu LED Philips yang hemat energi.

Dalam upaya meningkatkan persepsi konsumen yang baik pada produk lampu LED Philips, maka pihak marketing lampu LED Philips sebaiknya membuat iklan lampu LED Philips yang lebih menarik yang menyatakan bahwa banyak kegunaan yang diperoleh bila menggunakan lampu LED Philips terutama terkait menghemat energi dan ketahanan produk, agar dapat niat beli konsumen pada lampu LED Philip semakin meningkat. Kemudian untuk meningkatkan niat beli produk lampu LED Philips di Kota Denpasar, maka pihak marketing lampu LED Philips sebaiknya memperhatikan faktor-faktor yang mempengaruhi niat beli konsumen, seperti melakukan evaluasi harga, apabila konsumen merasa harga produk lampu LED Philips lebih mahal dibandingkan merek lainnya, serta memberikan pemahaman pada konsumen bila harga lampu LED Philips sesuai dengan kualitas dan manfaat yang diberikan. 


\section{REFERENSI}

Andanawari, Sartika. (2013). Hubungan antara tipe kepribadian dengan posttraumatic growthpada orang dengan HIV/AIDS (ODHA). Skripsi.Universitas Pendidikan Indonesia Bandung.

Amos Neolaka. (2008). Kesadaran Lingkungan. Jakarta: PT Rin-eka Cipta.

Anisah Rohdiyah. (2012). Kesadaran Lingkungan Dengan Niat Membeli Pada Konsumen Toko Sepeda Di Kawasan Jalan Katamso. Skripsi. Fakultas Ilmun Sosial dan Humaniora Universitas Islam Negri Sunan Kalijaga Yogyakarta.

Ansar, N. (2013). Impact of Green Marketing on Consumer Purchase Intention. Mediterranean Journal of Social Sciences, 4(11), 650-655

Baron. M.R dan Kenny. D.A.(1986). The Mediator-Mediator Variabel Distintion in Social Psychological Research : Conceptual, Strategis, and Statistical Consideration. Journal of Personality and Social Psychology. Vol. 51, No.6 pp: 1173-1182.

Burst Media. (2010). Nine in 10 Consumers Put "Green” in Daily Routine.

Chan, S. dan Lau, G. (2000), “consumers" trust in a brand and link to brand loyalty”, Journal of market Focused Management.

Chang, K.C., and Chen, M.C., (2011), Applying the Kano Model and QFD to Explore Customers' Brand Contacts in the Hotel Business: A Study of a Hot Spring Hotel, Journal Total Quality Management, 22(1), 1-27.

Chen, Mei-Fang (2009), Persepsi terhadap Makanan Organiks among Taiwanese as related to Health Consciousness Environmental Concerns, and the mediating effect of a healthy lifestyle, British Food Journal, Vol. 111 No.2, pp 165-178

Dedy Eko Siswanto. (2012). Pengaruh Persepsi Konsumen Pada Strategi Green Marketing Terhadap Sikap Konsumen Pada Green Product. Skripsi. Fakultas Ekonomi Universitas Muhammadiyah Surakarta.

Dumana, T., \& Mattilab, A. S. (2005). The role of affective factors on perceived cruise vacation value. Journal Tourism Management, 26, 321-323.

Fajrianthi Zatul Farrah (2005) "Strategi perluasan merek dan loyalitas konsumen" Insan Vol No 3,Desember 2005.

Ferdinand, A. (2000), Structural Equation Modelling dalam Penelitian Manajemen, Penerbit Universitas Diponegoro, Semarang. 
A.A. Ngurah Bagus Jaya Krisnandadan I Nyoman Nurcaya, Pengaruh Kesadaran ...

Follows \& Jobber (2000), Environmentally responsible purchase behavior: a test of a consumer model. European journal of marketing, vol. 34 No. 5, pp 723-746

Gil et al, (2001), Market segmentation and willingness to pay for organic product in Spain, International Food and Agribusiness Management Review, Vol. 3 No.3, pp 207-226

Goleman, D., (2009), Emotional Intelligence; Kecerdasan Emosional, Mengapa EI Lebih Penting dari IQ, PT. Gramedia Pustaka Utama, Jakarta.

Hair, Joseph Ferdinand, Black, et al, (2006), “Multivariate data analysis”, Sixth Edition

Hakim, Abdul. (2006). Analisis Pengaruh Motivasi, Komitmen Organisasi Dan Iklim Organisasi Terhadap Kinerja Pegawai Pada Dinas Perhubungan Dan Telekomunikasi Provinsi Jawa Tengah. JRBI. Vol 2. No 2. Hal: 165-180.

Hoyer, W.D. dan Maclnni, D.J. (2010). Customer Behavior , $5^{\text {th }}$ ed. SouthWestern: Cengage Learning.

Jonathan, Sarwono. (2006). Metode Penelitian Kuantitatif dan Kualitatif. Yogyakarta: Graha Ilmu.

Kim dan Chung (2011), Consumer purchase intention for organic personal care product, Journal of Consumer Marketing, Vol. 28 No.1, pp 40-47

Lee, K, (2009), "Gender differences in hong kong adolescent consumers' Green purchasing behavior”, Journal Of Consumer Marketing, Vol.26 No.2, pp.87-96.

Magistris \& Gracia (2008), The decision to buy organic foods products in Southern Italy, British Foods Journal, Vol. 110 No. 9, pp 929-947

Manget, J. (2009). Capturing the Green Advantage for Consumer Companies. The Boston Consulting Group.13 July 2009.

Mowen, J. (2007). Prilaku Konsumen. Jakarta : Erlangga.

Naratama, Nurcaya. (2016). Aplikasi Theory Of Reasoned (TRA) Dalam Menjelaskan Niat Beli Produk Hijau Di Kota Denpasar. E-Jurnal Manajemen Unud. Vol 5 No. 3 Page : 1770 -1799

Nesya Kasami Rahayu Yohanna. (2013). Persepsi Konsumen Terhadap Pengambilan Keputusan Pembelian Susu Sapi Perah di Kota Malang. Skripsi. Fakultas Ekonomi dan Bisnis Universitas Brawijaya Malang. 
Notoatmodjo, Soekidjo. (2012). Promosi kesehatan dan Perilaku Kesehatan. Jakarta :Rineka cipta

Ottman, J. A. (1993). "Green Marketing: Challenges and Opportunities for the New Marketing Age”, NTC Publishing Group, Lincol wood.

Paul J, Rana J (2012), Consumer behavior and purchase intention for organic food journal of Consumer Marketing, vol 29 no.6, pp 412-422

Ramezainian, M.R., Esmaeilpour, R. and Tondkar, H. (2009) The Effect of Green Products on the Purchase Process of Consumers, the 4th International Conference on Marketing Management.

Ridwan dan Engkos. (2011).Cara Mudah Menggunakan dan Memaknai Path Analysis. Bandung: Alfabeta

Rizky Kharismawan Shaputra. (2013). Penerapan Green Marketing Pada Bisnis Produk Kosmetik. Jurnal JIBEKA Volume 7, No 3 Agustus 2013 : 47-53.

Rizwan, M., Aslam, A., Rahman, M., Ahmad, N., Sarwar, U., \& Asghar, T (2013). Impact of green marketing on purchase intention: An empirical study from Pakistan. Asian Journal of Empirical Research, 3(2), 87-100.

Roberto Rodri'Guez-Ibeas. (2006). Environmental Product Differentiation and Environmental Awareness. Environmental \& Resource Economics (2007) $36: 237-254$

Saemian, S. and Zare'pour, E., The Main Components of the Green Marketing (Developing a Brand with an Environment Protection Approach), The First National Conference on Marketing and Pro-environment Protection Brands.

Schiffman, L. G. \& Kanuk, L. L. (2010).Consumer Behavior. 10th ed. Upper Saddle River, New Jersey: Pearson Prentice Hall.

Sugiyono. (2012). Metodologi Penelitian Kuantitatif Kualitatif dan $R \& D$. Alfabetha: Bandung.

Sumarsono, dan Giyatno, Y. (2012). Analisis Sikap Dan Pengetahuan Konsumen Terhadap Ecolabelling Serta Pengaruhnya Pada Keputusan Pembelian Produk Ramah Lingkungan. Performance, 15 (1): h: 70-85.

Yan, I. H., \& Chang, Y. W. (2006). The Consumers Cognition of Green Package. Journal of Oriental Institute of Technology, 26, 143-150

Zamroni Mahdy. (2014). "Studi Komparasi Konsep Pendidikan Dalam Keluarga Menurut Zahkiah Daradjat Dan Ki Hadjar Dewantara". Skripsi. Jurusan Kependididkan Islam Fakultas Ilmu Tarbiyah Keguruan Universitas Islam Negri Sunan Kalijaga Yogyakarta. 
A.A. Ngurah Bagus Jaya Krisnandadan I Nyoman Nurcaya, Pengaruh Kesadaran ... 